\title{
Hope Against Hype - Accountability in Biopasts, Presents and Futures
}

\author{
Nik Brown
}

\begin{abstract}
We are today wholly accustomed to being daily bombarded with (often competing) claims about the seemingly limitless potential and promise of transgenics, predictive medicine, reproductive science, bioinformatics and much else besides. Stories of new breakthroughs and advances mesh with 'our' culturally embedded sense of the steady march of enlightenment progress. Each announcement seems to index a sequential pulse in the accomplishment of the 'biotechnology revolution'. In more grounded terms, the talking-up of biotechnology prizes open the accounts of funding agencies and investors, in addition to winning the necessary support of various critical allies (patients, publics, regulators, etc). In equal measure, hyper-expectations feed into and fuel the complex counter concerns of oppositional cultures (new social movements, NGOs, etc). And yet these accounts of revolutionary potentially sit uncomfortably alongside our equally familiar experiences of unfulfilled promises, the awkward absence of future benefits, treatments, rewards and profits. This is not always the case, but more often than not, early hopes are rarely proportionate to actual future results. This paper charts key features in the 'dynamics of expectations', documenting the relationships between new hopes and emerging disappointments. It explores the routes of agency in the construction of the present's future and touches on the possibilities for greater accountability in the political economy of biotechnological expectations.
\end{abstract}

Keywords: hype, genomics, expectations

For every age there seems to be a particular group of activities that are taken to be somehow representative of the future. Whether that be nuclear power during the middle of the $20^{\text {th }}$ century, followed by the information revolution several generations later, or the biotechno- logical age at the close of the $20^{\text {th }}$ Century. Indeed, the opening of the $21^{\text {st }}$ Century seems to have fixed its future sights on all things small. Champions of the 'nanorevolution' now compete with new genetics for corporate and public patronage. Indeed, the appearance of a cu- 
riously new compound term, 'nanobiotech', nicely expresses the conjoining of otherwise competitive futures.

So it is often the case that, for a time at least, various areas of technological innovation become saturated with stratospherically high expectations of immanent and revolutionary change. Biotech is no exception and is today synonymous with the language and imagery of futuristic breakthroughs. The whole area is literally spilling over with heated aspirations, promises, expectations, hopes, desires and imaginings.

To a certain extent, such intense future orientation is essential to the rehearsal of the many possible prospective presents embedded in biotechnological research and discourse. And yet it is clear that hype has now become responsible for a great many current difficulties in the legitimacy of biotech.

First, hype about our radical biotech future seems to fuel and enflame widespread concerns and anxieties about risk too. That is, whether and what kind of future we would like our present to be given that so much opportunity could easily give rise to so much danger. Risk and opportunity are the flip sides of hyperbolic expectations, inflating one another in equal measure. The tendency to attribute incredible potential to biotechnology enflames concerns that things will go horribly wrong. And they might. Nevertheless, our experience to date is that actual events are rarely proportionate to early expectations.

Second, we are all no doubt familiar with several or more salient examples of early ambition giving way to disillusionment and any number of applications have turned out radically different to the way many people once anticipated.
Promise and risk are together vulnerable to the reflexive modern twist of solutions generating unanticipated problems (Beck et al., 1996) and the overall failure of predictive frameworks to anticipate the unanticipatable. The early promises associated with gene therapy have been confronted with unforeseen and highly complex problems, even in single gene defects where the approach seemed relatively straightforward (Martin, 2001). Transpecies transplants, once never very far from the headlines, have now drifted to the margins of the biotechnological imagination (Brown and Michael, 2003). The revolutionary futures foreseen for food production by industry visionaries have had to come to terms with the forceful futures of others, particularly sceptical Western consumers with different aspirations for nature, nutrition and consumption.

Biotechnology mirrors familiar patterns in the play of expectations and technological development. In the short term we tend to completely overestimate the practical capabilities of technologies. In the longer-term we tend to get it wrong altogether, with technologies occasionally taking us completely by surprise. Just as vulnerable to miscalculation is the willingness of target markets and users to eagerly embrace new applications or integrate them into their routines, lifestyles and consumption habits.

The Nobel laureate, Sydney Brenner recently offered a definition of 'the biotech firm' as an organisation that 'takes an idea and turns it into a concept'. As academics of science and technology, as well as participants in life science innovation, we seem to constantly be buffeted between cycles of hype and disappointment, awe and loathing in some- 
times bewildering swift succession.

This might be an exaggerated picture of biotechnological expectations but it does reflect some of the equally overstated and technologically deterministic futures associated with both green and red biotech. It also expresses our difficulties in making sense of the futures and expectations presently in circulation. In this paper I want to elaborate on what some in Science and Technology Studies now call the 'dynamics of expectation' - and use these insights to make sense of the future-oriented environment in which biotechnology's many activities are nested (Brown et al., 2003; Konrad, 2003). I am going to be drawing empirically on a number of research cases with which I have been involved, particularly research monitoring the changing fortunes of transpecies transplantation (Michael and Brown, 2000$2003^{1}$ ) - in addition to several other cases drawn from wider genomics.

To begin with, I want to explore the costs of hype both symbolically and materially to those who are persuaded by exaggerated futures. I will then outline ways in which our future-oriented speculations of the biotechnological future are embedded in two broad conditions. First, the paper explores the temporal conditions and patterns by which expectations change flexibly over time and the way in which representations of future-time have their roots in quite specific present day temporalities. That is, research fields differ radically in terms of their relative maturity and the degree to which various problems have had the time and opportunity to surface and thus reshape expectations. Second, expectations are also always embedded spatially in terms of the different locational positions and places within which future abstractions take shape. That is, contrasting expectations reflect differing points within a 'knowledge economy' of expectations. By 'knowledge economy' I mean that expectations are loaded with value, they are tradable and therefore form the basis of exchange relationships within 'communities of promise'. They also reflect asymmetries between people and groups in their access to information within the knowledge economy of expectations.

The conclusion will explore a crucial tension or dilemma in the social management of expectations. On the one hand, expectations and imaginative speculation are understood as fundamentally necessary real-time activities in order to mobilise the future into the present. That is, hype and the noisy clamour of future projection are indispensably central to the shaping of technology. And yet, on the other hand, we want to avoid the costly price of disillusionment, overshoot, hype and overselling. The final part of the paper will speculate on how to resolve the tensions between the apparent necessity of high expectations and the requirement for a more constructive engagement with future imaginings. Or rather, we might ask what are the prospects for reducing the damaging implications of failed futures?

\section{Hype's Costs}

Futures routinely vary from the expectations we once held of them. This is not unusual but indeed is a normal feature of the way in which people inhabit the future and the past. Most of us accept that our hopes and expectations will have to adapt to new and emerging cir- 
cumstances. And indeed, failure to adjust expectations in an ongoing and iterative way often leads to a widening gulf between rhetoric and more substantive (socio-material, etc) aspects of technological change.

The problem with the biotechnology sector is that, like many areas of innovation, expectations are sometimes both inflexible and reflect disproportionately exaggerated benefits and risks. This occurs for the very reason that future-abstractions are put into circulation in the first place - to have a 'performative' influence in real time (Michael, 2000). That is, hype is constitutive, it mobilises the future into the present. It is part of the repertoire through which a narrative path or story line is constructed for technologies (Deuten and Rip, 2000). And, as with any narrative or story, various 'actors' are scripted into the plot and must perform their part if the story is to be successful. Within communities of promise, expectations structure and organise a whole network of mutually binding obligations between innovators, investors, consumers, regulators and so on (van Lente, 1993; 2000). Technological change is therefore a process of constant oscillation between present and future tenses, between present problems and future solutions.

Now, these performative actions take place in acutely competitive environments where rival expectations each vie for ascendancy. The most vociferous voices are those most likely to have their expectation disseminated widely enough for the story or plot to become a more widely shared normative anticipation of the future. And equally, the greater is the likelihood that competing voices will contend that the future should be oth- erwise. This of course prompts the central analytical question of how it is that 'future scripts are stabilised around a specific set of expectations and practices' (Brown et al., 2000: 5).

So these then are two key features of the dynamics of expectations, particularly at the opening moments of innovation. First, the requirement to enunciate a story, a vision of the future and a means of getting there (Deuten and Rip, 2000). More usually, this will exhibit differing degrees of linearity and flexibility. Secondly, the promise will, almost necessarily, be exaggerated in order to command sufficient interest to enrol necessary allies and secure investment. And inevitably then, as time passes and circumstances change, unforeseen problems emerge, and early hype gives way to varying levels of disillusionment. When this occurs, such hopeful clusterings or 'communities of promise' fall apart and can be seen to migrate to new fields unsullied by hype's eventual disappointments.

However, hype is far from being a morally neutral activity. The costs of failure arising from overheated expectations and inflexible objectives have to be borne by someone, ultimately damaging reputations and trust. Very often, these changes in fortune can occur extremely abruptly. Harro van Lente (1993) shows how these rapid down-turns in expectations take place as a result of advocates of a technology having to maintain a rhetoric of hype even - or especially - as underlying problems become more apparent. As doubts increase, so too does the requirement to reinforce more positive futures. Until suddenly, the effort to maintain expectations becomes too high leading to an abrupt collapse and a new 
round of scapegoating and victim blaming.

Numerous commentators, both directly and indirectly, have noted the detrimental and costly impact of these dynamics on the biotechnology sector. One recently contended that 'too much 'genohype hurts everyone' (Caulfield, 2002) by detracting from the underlying longer-term value of basic science and overplaying unrealistic short-term expectations. It also tends to produce an artificially polarised form of ethical discourse at odds with the practical realities of the science.

Of course, these costs differ in quality and severity across different constituencies. With respect to red biotech, the enrolment of patient groups and health advocacy organisations has been crucial to promoting research trajectories and winning ethical and financial support. Of course, this varies enormously with, in some cases, health advocacy groups being highly influential in pushing for various avenues of research to be followed (Rabinow, 1999).

On the other hand, close links are often formed by industry with such groups in order to legitimate potentially difficult forms of research. This can be seen to have been strongly influential in the recent shaping of embryonic stem cell legislation whereby powerful alliances across patient groups produced highly influential policy lobbying. Participation in the research promise is a simultaneously moral and corporeal form of engagement (Rabeharisoa and Callon, 2002) and as Novas and Rose (2000: 506) note in the case of Huntingdon's Disease '... the responsible-genetic subject becomes active in the enterprise of science. This entails posting promising new re- search findings in the web forum. Materially, it often implies donating part of one's income towards funding a cure... [and] willingness to take part in clinical trials for potential therapies to cure HD...'

Similarly, innovation into tissue replacement technologies and transplantation has long been legitimated through powerfully emotive representations of desperately dependent patients. And yet, in retrospect, patient organisations are now sometimes more ambivalent about having been enrolled into the future articulated for technologies that simply did not fulfil their promise. In research by Mike Michael and myself we conducted discussion groups with patients and explored how people deal with the difficulties of attaching their hopes to promises that often go unfulfilled (Brown and Michael, 2003). The following extract is taken from a discussion group involving sufferers of Parkinson's disease, one of the groups who potentially stand to benefit from research into dopamine producing stem cells and xenografts. On the one hand, these people are intensely vigilant about new and emerging developments in medical technology. Yet they are also enormously sceptical having experienced successive episodes where glittering breakthroughs lead up blind alleys.

Rob: A lot of people have come to me over the last few years and said, "Have you heard the latest breakthrough?" And cause I've got Parkinson's I get the information on it and read it, but somehow it sort of gets lost and you don't hear of it again.

Darren: Yeah.

Cathy: You hear about it and then it's 
gone.

Darren: I can understand them making an announcement in the [Lancet] or something like that. That if they didn't issue it on general release until they were 12 to 18 months from the actual usage as far as the general public was concerned, I think psychologically it would be far better.

So the telling of sickness narratives in the context of technological promotion is a powerful means of creating research space, attractive investment and justifying morally challenging research (Mulkay, 1993; Brown, 1997). Such stories have enormous potency because they tell of the precarious futures of individuals who are desperate for treatment. In this way, the welding together of painful pathological biography and the fate of a biotechnological promise takes place at enormous cost to those who, for however long, are persuaded to share in the hope.

The costs of inflated promise can be seen even at the level of whole populations as well as patient groups. For example, the commercialisation of the Icelandic genetic register was legitimated on the basis that Icelanders would enjoy privileged access to new drug therapies in addition to a share in profits from pharmaceutical research and sales (Fortun, 2001; Palsson and Rabinow, 1999). In an early attempt to win the support of the electorate for the initiative, the government had pressed for company shares to be made available to Icelanders on the unregulated 'grey' market. On the basis of powerful promotional rhetoric about future potential, many members of the Icelandic population were sufficiently persuaded to put large amounts of personal finance into
DeCode. But since being listed, shares have slumped to less than a tenth of their original value. As one commentator recently observed, the talking-up of the 'wonderful opportunities of Iceland's genetic specialness was both reason to offer their blood for analysis and reason to dig into their pockets.... there is something unusually poignant about the DeCode story because those who have been burned have given the company not just their money but - with the blessing of their leaders - their genes'. (The Guardian, Oct 31 2002).

As the case illustrates, policy communities can become uncritically enrolled into unreasonable expectations of future potential and occasionally at great costs to those for whom they have duties of responsibility. This paper is being written as the UK Department of Health launches its white paper on genetics, suitably entitled 'Our Inheritance, Our Future'. Amidst strong criticism that it is overly optimistic and distracts attention from basic service provision, the report promises a $£ 10 \mathrm{~m}$ commitment to reviving gene therapy research over the next three years and the suggestion of clinical licenses being granted within five to ten years. This comes only six months after the suspension of gene therapy trials because two patients were found to have developed leukaemia in a French study (Science, $17^{\text {th }}$ Oct 2003).

In the contexts of governance and policy making, the need to produce attention-grabbing imagery for the genomics future comes at considerable costs in terms of revenue allocation and also in terms of appropriate safeguards against risk. Most regulatory frameworks operate, either explicitly or implicitly, in reference to some measure of cost-ben- 
efit analysis. That is, risks taken today are warranted by some perceived notion of potential benefit in the future. In the context of xenotransplantation, for example, hugely optimistic expectations of future benefits have been used to justify proportionately costly animal trial studies.

During the mid to late 1990s xenotransplantation research involving primates ranked amongst the most severe permitted under UK legislation. In the study by myself and Mike Michael, we encouraged respondents to reflect back on that period. One member of the regulatory body overseeing the field (UKXIRA) expressed concern that ' $h$ arm done to animals, particularly macaques, by this research is often underplayed, and the potential benefits are grossly overestimated' (UKXIRA member 1). For policy actors, operating at a distance from the basic research science, xenotransplantation seemed '... to be just around the corner... we just had to get over hyperacute rejection and then it would all be plain sailing...' (UKXIRA member 2). Hyping up the benefits and downplaying the cost was essentially necessary to an enterprise requiring large-scale financial investment and permission to undertake severely painful animal studies:

I think partly because there was a prominent scientist involved who raised expectations to an unrealistic level... and had this monocular view that... [transgenics] were going to solve it... clinical trials next week that sort of stuff; I think Novartis [pharma company] bought that thinking... I know it's being wise after the event... I and many of my colleagues did not realise it was going to be a long haul. You need belts and braces and several other things... on top of the expectations... (UKXIRA member 3).

Inevitably, as once distant futures advance towards the present, comparisons are made between past promises and present realities. In so many cases, the present fails to measure up to the expectations once held of it. This can have disastrous consequences for the reputations not only of individuals but entire innovation fields. As it was put recently, 'the biggest casualties of the hype could be the genomic research community and the biotechnology industry. The public will soon stop listening. And without public trust and support, genomic research will be unable to achieve its legitimate goals' (Caufield, 2002). Xenotransplantation in the UK followed the trajectory outlined above by Van Lente whereby the pressure to maintain the promise eventually gave way to a sudden collapse. It had become increasingly difficult to plaster over poor demonstrations of efficacy in the animal studies with future images of limitless supplies of tissues and organs (Brown and Michael, 2002). Almost overnight, funding of the UK company Imutran was withdrawn by Novartis just as reports were leaked about the concealment of negative findings.

These are then just some of the ways in which hype can turn out to have been counterproductive in the long run, whilst achieving the near term objectives of securing various financial and symbolic investments. The problem is that, over time, the dissonance between representation and reality becomes more apparent to those that have developed a stake in the promise. Rhetorical representations of the future are no doubt 
powerful animators of action and an essential feature of mobilisation. But at some point it must become evident that the imagination has taken on a solid material and substantive form. Materials and natures, the objects of biotechnological innovation, must have been seen to have behaved in a way that is congruent with the scripts once written for them (Akrich, 1992). But of course, the dreams of innovators have to take into account the fact that the objects of their innovation often seem to have futures of their own. Actants like immortal stem lines, genes, species, viral vectors, GMOs, all have a certain future-orientation though of course not in quite the same cognitive sense as human expectations. Futures are deeply embedded in technical processes, species continuities, cyclical routines and other temporalities which may turn out to resist enrolment into human aspirations articulated in language, metaphor and discourse (Adam, 1998; Mackenzie, 2002). When this occurs, the costs can be very high for any number of constituencies that have been enrolled in one way or another into the promise.

\section{Temporally Situated / Embedded Expectations}

Clearly then many of these expectations come at great cost to those who pin their hopes on various futures whether that be transplantable stem cells and xenografts, or the individualised drug regimes of pharmacogenomics, or higher nutritional crops for malnourished populations, or whatever. These costs are expressed in weakening trust relations between consumers, government policy and industry (Irwin and Michael, 2003;
Wynne, 1996). They are reflected in less stable market conditions, inhibiting necessary investment (Pixley, 2002). In terms of research investment, high expectations result in situations of famine and feast for research communities that might otherwise have benefited from longer term but more modest forms of patronage. Just as importantly, the emphasis of regulatory governance can sometimes be misdirected into areas of concern that are in actual fact unrealistic and impracticable.

So the obvious and logical question is how and whether we might ameliorate some of these costs, soften the disparities and volatilities of expectations? The first step in this direction must come, I suggest, from a better understanding of the 'situatedness' of expectations. That is, we need to reflect upon the actual contexts and conditions in which expectations, hype and future imaginings are embedded. I want to elaborate this situatedness according to two parameters, the temporal and the spatial.

By the temporal I mean that expectations, hypes and disappointments usually have a temporal patterning. Innovation concepts in biotechnology, as in other sectors, will vary according to whether they are presented as new or old. Understanding this temporal patterning helps us better appreciate how expectations of the future change over time. That is our presents are situated in relation to memories of past futures and future presents. By the spatial, I mean that expectations of a technology will be different (at any one time) for the many groups or constituencies involved, including policy makers, researchers, investors, patients, and so on. Again, understanding those spatial differences 
might be one of the first steps in what we might tentatively - even reluctantly call the democratisation of expectations.

For now I want to elaborate around the temporal situatedness of expectations and what this might offer in better understanding the dynamics of hope and hype. Some of these patterns have already been alluded to above but need to be opened up more fully here.

First of all it is clear that our expectations are constantly being made and remade on a moment by moment basis and that futures are never static but always have a changing role in the real time now. Indeed, one of the emerging constants in the theorisation of futurity is that it is only the present which is genuinely 'real' to us whereas the past and the future are only available to us through imagination and representation (Adam, 1990; Michael, 2000; Mead, 1932). Though I would suggest that this neglects some of the material and noncognitive ways in which pasts and futures are scripted in the present's materiality, it's artefacts, institutions, routines, etc (Callon, 1991; Akrich, 1992). So the past and the future do - in artefactual and material terms - have certain realities beyond the present. Nevertheless, how we reflect on the past and imagine the future always emerges from the real time work that we would like those representations to perform in the now.

So futures are performative (Michael, 2000). They are fundamental to producing the incentives and obligations that will be necessary to mobilise the necessary resources for a particular aspiration to be realised. And this performativity will be different for agendas which are novel or new, than for those which have become established or more mundane.
That is, the now of a new or novel field is quite different to the now of a field that may already have a track record behind it (whether that be a record of failure or success). Recent arrivals to the world of biotechnology (like nanobiotech, or embryonic stem cell innovation) often require an incredibly visionary momentum in order to command investment and collaboration.

One of the first points to make in relation to the temporal situatedness of expectations is that the intensity of expectations and their ambitious hyperbole is actually indicative of the emergence of new networks and activities (Brown and Michael, 2003: 16). Hype corresponds to a particular phase in the career of innovations. The whole language of novelty, newness and revolutionary potential is actually part and parcel of the hyperbolic discourse surrounding the early or opening moments of resource and agenda building (Campbell, 1998; Brown, 2000).

Second, the idea that an innovation will substitute or replace existing ways of doing things is another constant characteristic of innovations in their earliest phases (Geels and Smit, 2000). If we cast our minds back, gene therapy, it was once thought, would entirely dispense with the need for pharmaceutical medicines and compounds. The medicinal approach to managing symptoms would be replaced by a therapeutic framework based on the idea of genes as the cause of diseases from within and genes as a means of countering our vulnerability to disease from without.

As it happens, gene therapy has turned out to have niche applicability in terms of expanding our understanding of viral vectors and so on. It also illustrates the way in which biotechnologi- 
cal approaches, over time, move through cycles of legitimation and delegitimation. The mixed successes and failures of using GT to treat the immune deficiency syndrome X-SCID in both the UK and France is a poignant expression of these knife-edge balances between hope and disappointment. It is the second time around for stem cells too, building on once largely discredited ambitions surrounding regenerative medicine from a decade or more ago.

To this extent it is almost inevitable that expectations will be inflated and will therefore be temporally followed, when reflecting on the past, with some degree of disillusionment in a promise that went unfulfilled or turned out quite differently. When looking back on these past futures (what Michael and myself describe as 'retrospecting prospects' [2003]) it often seems to be the case that hype tends to entirely overestimate the near or medium term potential of a field whilst completely misunderstanding longer term value altogether.

There's probably no better example of these dynamics than the Human Genome Project itself. Evelyn Fox Keller recently made the observation that much of the early promotional thrust of the HGP towards a completion of a 'draft' was based on the idea that the sequence would itself be the great milestone in understanding the genetic basis of life and disease. And yet of course the contribution of the sequence to an understanding of function is far from straightforward. She recalls a statement by Walter Gilbert in his 'Vision of the Grail' where he looks forward to a moment when 'three billion bases of sequence can be put on a single $\mathrm{CD}$, and one will be able to pull a CD out of one's pocket and say, 'here is a human being, it's me' (Gilbert, 1992). 'Today', writes Fox Keller (2000: 6), 'almost no one would make such a provocative claim. Doubts about the adequacy of sequence information for an understanding of biological function have become ubiquitous...'. These kinds of expectations, and the threat of 'piracy' by commercial sequencing, may have been instrumental in speeding the HGP towards an announcement of completion but it remains a far cry from the expectations of a decade ago in respect to function and variation.

Of course few of the ups and downs in the hype and disappointment cycle have escaped the notice of seasoned participants in research and public debate. Discussions about 'hype' itself now seem as common as discussions about the whole project of genetic innovation. And many of these half embarrassed reflections on early expectations have given many cause to be more cautious about the expectations of genetic innovation that we hold today. Marcus Pembrey recently wrote:

There is a tendency, always present, to fall into the trap of thinking that the main elements of understanding life or health have been discovered and that all that is now left is filling in the detail. We feel we have an adequate explanation, partly because people with vested interests from teachers to venture capitalists keep telling us so. Why should we expect some new discovery to 'turn everything on its head'? We are back to 'the secret of life' claim, in which the DNA sequence is somehow extracted from the living process to be 'put in charge', where conception is reduced to the mixing of two sets of genes. It was necessary to understand DNA to know the nature of life, but that doesn't mean it is sufficient. The big impacts on the 
genetics of common disease in the next 20 years are likely to involve processes that are currently unknown or barely hinted at in the daily avalanche of biomedical research data (Pembrey, 2003).

The point then is that expectations are temporally situated and our orientation to the future needs to take account of where we are temporally in relation to a number of key factors. Primarily, research fields differ in respect to their temporal maturation and exhibit differing degrees of novelty. That is, the newer or more unfamiliar a research agenda is, the greater will be the need to use hype as a means of defining roles, responsibilities and duties. We can also expect that hypothetical future benefits will be used to legitimate costs in the present, that may in the future turn out to have been morally unjustifiable. Over time, as research agendas mature, we can also expect that various material and social problems will become more apparent. Much of the early momentum and investment will find utility in terms of niche and indirect applications in the medium term but will not entirely substitute present ways of doing and thinking about things. In the much longer terms, early expectations are usually seen to have entirely overlooked the real agents of change.

\section{Spatially Situated / Embedded Expectations}

Now in addition to thinking about the passage of time and matters of 'when' (past, present and future tenses) we also have to consider questions of 'where' and 'who'. That is, expectations are always situated in various relationships across whole communities of partici- pants within the futurority of biotechnology. This then is part of the difficult and challenging business of uncovering the complex chains of agency that together contrive to produce various representations of the future, thus guiding action and building agendas. Futures are never simply homogenous singular representations but are differently interpreted and engaged across constituencies as diverse as the clinic, industry, policy making, consumers and users. And of course, most of us will inhabit at least some of these different identities simultaneously.

Many of the cases already alluded to above demonstrate that expectations are far from uniform but are instead the outcome of struggles and contests between different voices each vying for control. The future-and its associated meta-concept of 'progress' - emerge through an unstable field of language, practice and materiality in which different groups compete for the right to represent near and far term developments. And like any other contested field, actors engage in such struggles with unequal access to the resources with which futures are manufactured. These resources are compound mixtures of experimental, evidential, material, political and ethical assets.

Crucially, such spatial unevenness or 'lumpiness' prompts searching questions about where different constituencies are located in what we might call the 'knowledge economy of expectations'? Where do expectations of the future originate and by what means do they come to take hold of our imaginations and actions? Clearly, in the context of this paper, answers to these questions are going to be modest. Nevertheless, it 
is possible to offer a few observations, which together help us understand the spatial situatedness of expectations and which encourage us to reflect on our different placements and positions within future imaginings about the biosciences.

Now there are any number of routes into a discussion of this kind but the opening which appeals most to me is the press release, a ubiquitous communications device through which research communities disseminate findings and claims about the future on a rapid and indeed globalised scale. Press releases traverse the communications conventions of science on the one hand and the media on the other. Importantly, they are points of translation through which laboratory practice and peer reviewed science publishing are transformed such that they become available to wider public consumption.

In the parlance of Science and Technology Studies, press releases have an 'immutable mobility' (Latour, 1987) in that they manage to remain stable as they pass across multiple sites within the knowledge economy of expectations. They translate and stabilise information that might otherwise fail to be noticed or picked up in the wider world. Their purpose is persuasion. They are the productions of research communities seeking to raise the profile of their work as a means of persuading potential patrons of the benefits of investment or sceptical publics of future benefits.

Importantly, press releases that emerge from research communities are characterised by a language and discourse that would never appear on the pages of peer reviewed science journal texts (Nelkin, 1995). In particular, much of the careful qualification of scientific texts is abandoned for the more strident language of 'breakthrough', 'the first', 'the best', 'never before'. In other words, science communities suddenly metamorphose themselves into the highly competitive news conventions of the media code. When press releases arrive on the desks of science correspondents there is often precious little time to interrogate claims about new cures and revolutionary promises.

When we examine the journeys or travel that biotechnology expectations make in their passage from laboratory to the news page, it is absolutely clear that it is no longer possible to go on simply blaming the media for hyping things up. Research communities are crucial participants in the production of hype. This is then a spatial dynamic whereby it is possible to see, as we move from the laboratory to the wider public world, the progressive accumulation of expectations around otherwise quite abstract bits of data and knowledge. Although, many controversies in science, particularly those involving allegations of fraud, arise because research scientists sometimes bypass their lab's media personnel and release information which might otherwise have not been sanctioned by a press office (Hagendijk and Meeus, 1993).

Numerous laboratory studies have pointed to the complex uncertainties in which the production of new knowledge is steeped (Latour and Woolgar, 1979; Lynch, 1997). Lab work is characterised by difficult decisions about the meaning of findings, alternative explanations, whether devices can be relied upon to function properly and indeed whether any of the work will eventually add up to anything that has usefulness down 
stream and out there in the practical world. And yet most of these uncertainties will be lost the further we move in time and space away from the material complexity of bench science (MacKenzie, 1990; Collins, 1990). There is then a spatial and of course temporal patterning to the production of expectations in which we can observe an accretion of certainty and confidence about future claims.

So the press release is an important axial point in this process of translation from the conventional codes of scientific representation within science communities to the codes of news and science reportage. Thus, news is exactly that, it has to be new - it has to be novel, unprecedented and recent (van Dijk, 1988). A scientific paper on the other hand is not necessarily about reporting new things but about how relatively newish evidence either fits into existing frameworks of knowledge or adapts existing theory. It is in fact extremely rare for something completely new to find its way into Nature or Science. Scientific news is more usually old news. Findings often move painfully slowly through the mangle of experimental practice, laboratory notes, writing up, paper submission, peer review, successive amendment, finally to find their way in to a scientific journal. The end result, a paper in Nature or whatever, bares little resemblance to the kinds of uncertainties that are rampant in the laboratory. But nevertheless, most authors of scientific articles are prepared to include at least some qualifying clauses - alternative explanations for the phenomenon being reported. But, notwithstanding these uncertainties, the authors will offer a main explanation to the judgement of their peers.

So when we look at the writing of press releases and scientific journal articles side by side it is clear to see that the representations of what took place in the laboratory are actually quite inconsistent and certainly reflect different versions of future relevance. Research communities switch sometimes quite effortlessly between different identities. On the one hand, we have claims to the disinterested neutral observation of laboratory events and cautious propositions couched in some degree of uncertainty. On the other hand, we have entrepreneurial claims about the far-reaching value and utility of what took place (Brown, 2000).

Now, even within the press release it is sometimes difficult to police the boundaries between the uncertainties of scientific research values and the certainties of news reportage. What follows is a wonderfully cryptic formula that is usually attached to most press releases issued within the US by biotech companies. It makes the admission that whilst the press release makes claims about the future, it's authors would rather not like to take responsibility should their promises not come true.

Certain statements in this press release are forward-looking. These may be identified by the use of forward-looking words or phrases such as "believe," "expect," "anticipate," "should," "planned," "estimated," and "potential," among others. These forward-looking statements are based on PE Corporation's current expectations. The Private Securities Litigation Reform Act of 1995 provides a "safe harbor" for such forwardlooking statements. In order to comply with the terms of the safe harbor, PE Corporation notes that a variety of fac- 
tors could cause actual results and experience to differ materially from the anticipated results or other expectations expressed in such forward-looking statements. The risks and uncertainties that may affect the operations, performance, development, and results of Celera Genomics' businesses include but are not limited to (1) early stage of operations and uncertainty of operating results; (2) no precedent for Celera Genomics' business plan; (3) uncertainty of value of polymorphism data; (4) initial reliance on pharmaceutical industry; (5) high dependence on key employees; (6) uncertain protection of intellectual property and proprietary rights; (7) highly competitive business; (8) need to manage rapid growth; and (9) other factors that might be described from time to time in PE Corporation's filings with the Securities and Exchange Commission. (PE-Corporation January 20, 2000) http:// www.celeradiscoverysystem.com

The uncertainty clause gives the promise-maker some insulation or 'safe harbor' from the possibilities of litigation by frustrated investors when promises go unfulfilled, as they so often do. The caveat can just as easily be seen as a poignant expression of the tension between the requirement to communicate and envisioned desired future, and the equally necessary requirement to prepare for other less desirable outcomes of present speculation. In such cases, the promise makers want their cake and they want to eat it too - they want to generate a sense of certainty in a future expectation whilst also covering their backs if and when things turn out differently. The uncertainty clause also has an important spatial location both within the text itself buried as it is below the main story of the press release, and also within the US legislature. In other na- tional spaces, press releases about science on the whole do not embody such highly routinised qualifying statements.

What I have tried to show here is that expectations have a spatial dynamic whereby the further we travel from the source of knowledge production, the more colourful and flamboyant become the promissory properties of knowledge. Gene sequences are translated as secrets of life. The complexities of viral vectors are easily translated as cures for immune deficient children. The production of small neural stem cells are heralded as the breakthrough desperately awaited by dopamine deficient Parkinson's disease patients and the many thousands or more suffering from spinal and brain injuries.

This then becomes a highly complex environment in which expectations circulate, are reinforced or contested in one way or another. Mutual enrolments emerge between research groups, patient organisations, NGOs, policy communities and pharmaceutical companies. It's clear that we have only just begun to understand the ways and means through which laboratory entities become objects of widely shared speculative promise. But what is just as clear is that, as the original contingencies of knowledge production fall from view, such wider communities are left with few contextual resources with which to judge the veracity of promissory claims. Spatial remoteness drives a wedge between the privately cautious world of bench science and wider constituencies within the knowledge economy of expectations. 


\section{The Hype Dilemma}

Now, I want to change focus slightly by exploring a troubling dilemma that has been developing as this story has unfolded. The future in the present is stalked by a catch 22 and it looks something like this: On the one hand, we accept that expectations are constitutive and performative and that hype plays a fundamentally important role in organising our future present/s. On the other hand, hype is a source of 'overshoot', ultimately damaging credibilities and reputations. Communities of promise are constantly presented with the difficulty of judging the veracity of future claims. And we engage with these processes of judging whilst knowing that things rarely turn out as expected.

The dilemma is one in which we use our experience to interrogate expectations whilst also recognising that we cannot place ourselves outside the world of expectations as if we were objectively disinterested observers. Futures are contingent, they are imagined, fought for, resisted and embraced in the present - in order to draw an imagined future into the real-time now. But it would be impossible to fully disentangle present hype from future reality.

Indeed, as Franklin (349: 2001) points out in respect to the contested expectations build up around stem cells, '... it is a mistake to think that we can somehow factor out the hype, the media or the work of the imagination to exaggerate either the promises or the risks of new technology. This is not going to be possible, now or in the future, because it is precisely the importance of imaging a future yet to be that fundamentally defines the whole issue of the new genet- ics and society'.

This 'constructivist' approach to expectations is quite different from the way expectations tend to be framed within conventional economics. Much of classical economics, and even 'rationale economics' from the 1960s, seems to draw a realist line or distinction between people's expectations on the one hand and the 'real' underlying fundamentals or worth of something on the other. When hype occurs, it does so because people start investing in the expectations and not the fundamentals. A crash occurs when the difference between real and artificially inflated values becomes inescapably obvious (Koppl, 2002; Pixley, 2002). The realist position assumes that there is a calculable difference in the present between the expectations and the real worth of something such that expectations can be adjusted 'rationally'. The more rational this process of checking becomes, the less susceptible economies are to inflationary and deflationary pressures.

Whilst this emphasis on checking is valuable it is also conceptually problematic for a number of reasons. If we accept that anticipation is constitutive of value, then we logically cannot differentiate between our expectations of the biotechnologies and what in reality those biotechnologies are, both in the present and in the future. Those 'underlying fundamentals' are themselves future abstractions, projections that alter the now. Fundamental value is then quite inseparable from expectations in either conceptual or empirical terms. It cannot be calculated independently from our expectations in order to determine whether or not hype is taking place. 
So is there room for better integration between different expectations, desires and imaginings? On the whole this needs to stem from a critical understanding of the situatedness of expectations both in terms of time and space. These temporal and spatial features of the knowledge economy of expectations represent an important step in understanding how expectations accumulate value - and indeed sometimes dramatically lose it again. It is also an important step towards critiquing the role of future abstractions in structuring and organising relationships between the different participants (both human and nonhuman) in biotechnological innovation.

This calls for greater temporal and spatial reflexivity such that we can move away from normative futures and towards a position that sees expectations rooted in particular times and places. We need to do this recognising that a reflexive engagement with expectations cannot logically rule out hype but only become more sensitive to the many hidden futures that hype so often silences.

Much of the task lies in greatly reworking epistemological asymmetries within the knowledge economies of expectations such that private uncertainties within innovation communities (the laboratory in particular) find routes into wider public spaces and times. What happens to uncertainty as expectations make their way from 'in here' to 'out there'? New discourses and practices clustered around transparency, to some extent at least, suggest that these kinds of pressures are now on the agenda for communities of promise. But again, transparency is far from innocent in contributing to the boundaries between public and private knowledge, 'front stage' and 'back stage'. When is it ever possible to say that one's expectations are based on full and unconditional access to once obscured information, or all the facts? This is especially problematic as science increasingly exchanges the institutional body language of authority ('trust me') for authenticity ('show me' or rather 'believe me when I tell you...') (Brown and Michael, 2002). Nevertheless, whilst there are undoubtedly endemic problems in the surge to transparency, much of its weakness lies in how the principle is instituted and therefore whether it can contribute to more credible expectations.

We also have to recognise that opening up expectations to greater pluralizing pressures will not make biotechnology's futures less contested, but will very probably make them more so. Again, the 'democratisation of science' - and of the expectations embedded in science hinge on their institutionalisation and whether consumers of promise are simply being presented with the same old hype now dressed up in precautionary rhetoric. To date, democratisation here seems to point to science increasingly populating public futures and all too rarely the other way around (Elam and Bertilsson, 2002). The 'post-normal science' thesis (Ravetz, 1999) which sees science increasingly dependent on wider political and public aspirations should, it appears, be received with caution. The emergence of that highly suspect figure 'the scientific citizen' hints at just which way the traffic seems to be moving and who is driving.

Whatever our answers to these questions, we can only hope rather than foretell that our engagement with the dynamics of expectations may lead to more 
workable desires for the future - and who knows?

\section{Acknowledgements}

Much of the thinking behind this paper arose in the course of long and fruitful discussions with Harro van Lente, Arie Rip, Mike Michael and AndrewWebster. I would particularly like to thank organisers of the Biotech Society meeting in Helsinki 2003 for inviting me to address the question of hype more directly. Parts of this discussion are based on the project 'Xenotransplantation: Riskidentities and the Human/Nonhuman interface' funded by the UK Economic and Social Research Council [L218 25 2044].

\section{Notes}

1 Michael, M. \& Brown, N. 2000-2003 Xenotransplantation: risk identities and the human/nonhuman interface, research project funded by the UK Economic and Social Research Council.

\section{References}

Adam, B.

1998 Timescapes of Modernity: The Environment and Invisible Hazards. London: Routledge.

Adam, B.

1990 Time and Social Theory. Cambridge: Cambridge University Press.

Akrich, M.

1992 "The De-Scription of Technical Objects", in Bijker, W. and J. Law (eds.) Shaping Technology/Building Society: Studies in Sociotechnical Change. Cambridge: MIT Press.

Beck, U., Giddens, A. \& Lash, S.

1996 Reflexive Modernisation. Cambridge: Polity Press.
Brown, N. \& Michael, M.

2003 "A Sociology of Expectations: Retrospecting Prospects and Prospecting Retrospects.” Technology Analysis and Strategic Management: 15(1): 3-18.

Brown, N., Van Lente, H \& Rip A.

2003 "Expectations In and About Science and Technology", Background Paper for the Expectations in S\&TWorkshop, 1314 June, Utrecht, The Netherlands.

Brown, N. \& Michael, M.

2002 "From Authority to Authenticity: Governance, Transparency and Biotechnology." Health, Risk and Society 4(3): 259-272.

Brown, N., Rappert, B. \&Webster, A. (eds.)

2000 Contested Futures: A Sociology of Prospective Techno-Science. Aldershot: Ashgate.

Brown, N.

2000 "Organising/disorganising the Breakthrough Motif: Dolly the Cloned Ewe Meets Astrid the Hybrid Pig," in Brown et al. op cit.

1997 Ordering Hope-Xenotransplantation, an Actant-actor Network Theory Account. PhD thesis, Lancaster University.

Campbell, C.

1998 "Consumption and the Rhetorics of Need and Want." Journal of Design History 11(3): 235-246.

Collins, $\mathrm{H}$.

1990 Artificial Experts: Social Knowledge and Intelligent Machines. Cambridge Mass.: MIT Press.

Callon, $\mathrm{M}$.

1991 "Techno-economic Networks and Irreversibility", in Law, J. (ed) Sociology of Monsters. Essays on Power, Technology and Domination. London: Routledge.

Caulfield, $\mathrm{T}$.

2002 "Science, with a Bang: The hype unleashed in the rush to cash in on the genetic revolution threatens to doom important research", (8 July) Ottawa Citizen A15; also in the Edmonton Journal as “'Genohype' and the Genetic Revolution" (8 July 2002).

Deuten. J. \& Rip, A.

2000 "Narrative Infrastructure in Product Creation Processes." Organization 7(1): 69-63. 
Elam, M. \& Bertilsson, M.

2002 “Consuming, Engaging and Confronting Science: the Emerging Dimensions of Scientific Citizenship." STAGE (Science, Technology and Governance in Europe), Discussion Paper One, March.

Fischer, S. (ed.)

1980 Rational Expectations and Economic Policy.

Fortun, M.

2001 "Mediated Speculations in the Genomics Futures Markets.” New Genetics and Society 20: 139-156.

Fox Keller, E.

2000 The Century of the Gene. Harvard, MT: Harvard University Press.

Franklin, S.

2001 "Culturing Biology: Cells Lines for the New Millennium.” Health 5(3): 335354.

Geels, F.W. \& Smit, W.A.

2000 "Failed Technology Futures: Pitfalls and Lessons From a Historical Survey", in Brown, et al, op cit.

Gilbert, W.

1992 "Vision of the Grail." Pp.83-97 in Kelves, L. \& Hood, L. (eds) The Codes of Codes. Hagendijk, R. \& Meeus, J.

1993 "Blind Faith: Fact, Fiction and Fraud in Public Controversies Over Science." Public Understanding of Science 2: 391-415.

Irwin, A. \& Michael. M.

2003 Science, Social Theory and Public Knowledge. Milton Keynes: Open University Press.

Konrad, K.

2003 “The Social Dynamics of Expectations on New Information and Communication Technologies." Paper presented at Expectations in S\&T workshop, 13-14 June, Utrecht, The Netherlands.

Kopple, R.

2002 Big players and the Economic Theory of Expectations. Palgrave.

Latour, B.

1987 Science in Action. Milton Keynes: Open University Press.

Latour, B. \&Woolgar, S.

1979 Laboratory Life. Princeton: Princeton University Press.
Lynch, M.

1997 Scientific Practice and Ordinary Action: Ethnomethodology and Social Studies of Science. Cambridge: Cambridge University Press.

Mackenzie, A.

2002 Transductions: Bodies and Machines at Speed. London: Continuum.

MacKenzie, D.

1990 Inventing Accuracy: An Historical Sociology of Ballistic Missile Guidance. Cambridge MA: MIT Press.

Martin, P. A.

2001 "Great Expectations: the Construction of Markets, Products and User Needs During the Early Development of Gene Therapy in the USA", in Coombs, R., Green, K., Richards, A. and Walsh, V. Technology and the Market: Demand, Users and Innovation. Cheltenham: Edward Elgar.

Marvin, C.

1988 When Old Technologies Were New. Oxford: Oxford University Press.

Mead, G.H.

1932 The Philosophy of the Present. Chicago: Chicago University Press.

Michael, M.

2000 "Futures of the Present: From Performativity to Prehension." In Brown, et al., op cit.

Mulkay, M.

1993 "Rhetorics of Hope and Fear in the Great Embryo Debate." Social Studies of Science 23(4): 721-742.

Nelkin, D.

1995 Selling Science (Revised Edition). Freeman: New York.

Novas, C. \& Rose, N.

2000 "Genetic Risk and the Birth of the Somatic Individual." Economy and Society 29(4): 485-513.

Pálsson, G. \& Rabinow, P.

1999 "Iceland: The Case of a National $\mathrm{Hu}$ man Genome Project." Anthropology Today 15(5): 14-18.

Pembrey, M.

2003 "Putting Genes in Their Place." BioNews.org.uk $29^{\text {th }}$ May.

Pixley, J.

2002 "Finance Organisations, Decisions and Emotions." British Journal of Sociology 53(1): 41-65. 
Rabeharisoa, V. \& Callon, M.

2002 "The Involvement of Patients' Associations in Research." International Social Science Journal 54(171): 57-63.

Rabinow, P.

1999 French DNA: Trouble in Purgatory. Chicago: Chicago University Press.

Ravetz, J.

1999 "What is Post-normal Science?" Futures 31: 647-653.

Van Dijk, T.A.

1988 News as Discourse. The Netherlands: Lawrence and Erlbann Associates.

Van Lente, $\mathrm{H}$.

1993 Promising Technology-The Dynamics of Expectations in Technological Developments. Enschede.

2000 "From Promises to Requirement", in Brown, et al. op cit.

Wynne, B.

1996 "May the Sheep Safely Graze? A Reflexive View of the Expert-lay Knowledge Divide." In Lash, S. Szerszinski, B. and Wynne, B. (eds) Risk, Environment and Modernity: Towards a New Ecology. London: Sage.

Nik Brown

Science and Technology Studies Unit (SATSU),

Department of Sociology,

University of York

ngfb1@york.ac.uk 